\title{
The engagement and retention of non-profit employees in Belgium and South Africa
}

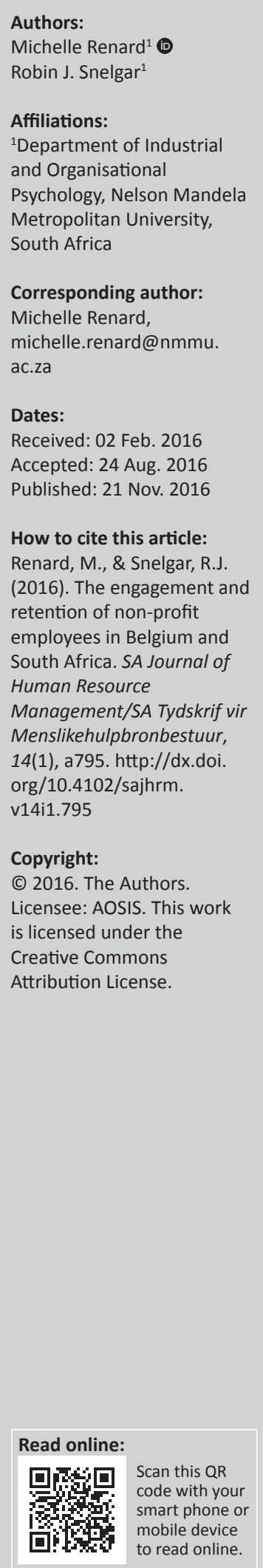

Orientation: A lack of qualitative research exists that investigates work engagement and retention within Belgium and South Africa, particularly within the non-profit sector.

Research purpose: The study aimed to gather in-depth qualitative data pertaining to the factors that promote work engagement and retention amongst non-profit employees working within these two countries.

Motivation for the study: Because of scarce funding and resources, non-profit organisations are pressured to retain their talented employees, with high levels of turnover being a standard for low-paid, human-service positions. However, when individuals are engaged in their work, they display lower turnover intentions, suggesting the importance of work engagement in relation to retention.

Research design, approach and method: Non-probability purposive and convenience sampling was used to organise in-depth interviews with 25 paid non-profit employees working on either a full-time or a part-time basis within Belgium and South Africa. Thematic analysis was used to analyse the qualitative data produced.

Main findings: Participants were found to be absorbed in, dedicated to and energised by their work, and revealed numerous aspects promoting their retention including working towards a purpose, finding fulfilment in their tasks and working in a caring environment.

Practical/managerial implications: Non-profit organisations should develop positive work environments for their employees to sustain their levels of work engagement, as well as place significance on intrinsic rewards in order to retain employees.

Contribution: This study provides insights into the means by which non-profit employees across two nations demonstrate their enthusiasm, pride and involvement in the work that they perform. It moreover sheds light on the factors contributing to such employees intending to leave or stay within the employment of their organisations.

\section{Introduction}

According to Schaufeli and Bakker (2003), the emergence of positive organisational psychology has resulted in positive aspects of well-being becoming popular in research studies. Work engagement is one such aspect (Schaufeli \& Bakker, 2003), described as 'a positive, fulfilling, work-related state of mind that is characterized by vigour, dedication, and absorption' (Schaufeli, Salanova, González-Romá \& Bakker, 2002, p. 4). Employees have a desire to be engaged in work that helps them feel that they are positively contributing to something larger than themselves (HayGroup, n.d.). Along this line, Lin (2009) found that employees who worked in organisations that were perceived to demonstrate corporate citizenship behaviours exhibited high levels of work engagement. This suggests that employees who work for organisations that are socially responsible, as in the case of non-profit organisations (NPOs), will exhibit high levels of work engagement. Consequently, one can be led to believe that NPO employees would by nature be engaged in their work, especially in choosing to work in their organisations because they perceive that they are contributing to society or making a difference in the lives of others.

However, Glicken and Robinson (2013) explain that individuals who work within helping professions are prone to compassion fatigue, a condition in which individuals experience a decline in their ability to care for others and feel joy. This typically occurs when high levels of energy and compassion are expended, yet little internal peace or positive feedback is received in return for such efforts. Employees working in NPOs may be prone to such fatigue because 
their purpose is to operate to benefit the lives of others. If such fatigue is experienced, NPO professionals may begin to experience what Glicken and Robinson (2013) refer to as secondary traumatic stress because of the emotional trauma that results from caring for others in need. Such individuals bear the risk of decreased levels of engagement, which could lead to them exiting the NPO sector. However, when individuals are engaged in their work, they display lower turnover intentions (Bothma \& Roodt, 2013; Park \& Gursoy, 2012; Robyn \& Du Preez, 2013; Schaufeli \& Bakker, 2004).

Kuttner (2008) mentions that high levels of turnover are the industry standard for low-paid, human-service jobs, which provides insight into Sokkie's (2013) finding that a primary issue for human resources in the non-profit environment is the retention of highly skilled and qualified employees. Surtees, Sanders, Shipton and Knight (2014) mention that retention is as important for NPOs as it is for organisations operating in other sectors, because NPOs operate with the lowest overheads possible and, thus, cannot afford absences or potential waste in terms of employee investments. Owing to the fact that NPOs face pressures in the form of being forced to compete for scarce funding and resources, they must be able to retain their talented employees as well as maximise their performance in order to avoid collapse (Bussin, 2013). Consequently, Ryder (2008) states that NPOs must begin to focus on employee retention if they want to guarantee their own long-term sustainability and program delivery. Philanthropy News Digest (2012) is in agreement with this fact, mentioning that NPOs need stronger retention programmes, because three quarters of the NPOs mentioned in their article claimed to have no formal retention strategies in place. Given the fact that NPO employees are, on average, paid less than private sector employees (Tippet \& Kluvers, 2009), there also exists the possibility that extrinsic rewards are not the best means to retain NPO employees.

\section{Purpose}

As service organisations, NPOs play a significant role in society, particularly with regard to the economic, cultural and social development of a country (Lynn, 2003). Despite the constraints experienced within the non-profit sector, organisations operating within this sector have managed to make significant social contributions (Lynn, 2003). Consequently, understanding and facilitating the engagement and retention of NPO employees will assist in ensuring the sustainability of such organisations.

This study therefore aimed to gather descriptive data related to work engagement and retention in an attempt to explore how these aspects might be promoted amongst non-profit employees. Specifically, the authors collected data within Belgium and South Africa because of the limited work engagement and retention research that has been conducted on paid NPO employees within these two countries (see
Buys \& Rothmann, 2010; De Gieter, De Cooman, Pepermans \& Jegers, 2008; De Gieter, Hofmans \& Pepermans, 2011; Leroy, Anseel, Dimitrova \& Sels, 2013 for examples of studies investigating work engagement or retention amongst nonprofit employees in these countries; however, none of these studies utilised a qualitative method or investigated both work engagement and retention in their analysis). The purpose of this article is not to make a cross-cultural comparison between Belgium and South Africa, but merely to provide in-depth insights into factors influencing work engagement and retention amongst NPO employees working within these countries.

Numerous empirical quantitative studies have assessed work engagement and retention within the two countries under study utilising profit organisations as a sample (see, for example, Rodríguez-Muñoz, Baillien, De Witte, MorenoJiménez and Pastor [2009] and Vander Elst, Baillien, De Cuyper and De Witte [2010] for Belgian work engagement research; Kyndt, Dochy, Michielsen and Moeyaert [2009] and Derycke et al. [2010] for Belgian turnover intention research; Stander and Rothmann [2010] and Jacobs, Renard and Snelgar [2014] for South African work engagement research; and Bothma and Roodt [2013] and Van Der Vaart, Linde, De Beer and Cockeran [2015] for South African turnover intention research). However, the type of work performed by employees in NPOs, as well as the environments and situations to which they are exposed, is often different from that of employees working in profit organisations, implying that direct inferences for NPO employees cannot be made on the basis of the studies mentioned.

Moreover, qualitative research investigating work engagement and retention within these countries is lacking, despite the fact that making use of in-depth interviews allows researchers to gather thorough personal accounts of data, investigate personal contexts and explore issues in detail (Lewis \& McNaughton Nicholls, 2014). Qualitative research offers a distinct advantage because it elaborates on the contextual richness of individuals' lives, thus giving meaning to their experiences in real-world conditions (Yin, 2011). Taken together with the lack of research pertaining to these constructs within the non-profit sector specifically, this presents a gap in research which this study will attempt to bridge.

\section{Literature review}

\section{Work engagement}

'To be engaged' implies that an employee exhibits a 'persistent and pervasive affective-cognitive state', which is not focussed on a specific event, object, behaviour or individual (Schaufeli et al., 2002, p. 74). Engaged employees feel absorbed in, dedicated to and energised by their work, as opposed to employees who are burnt out and experience cynicism and exhaustion (Schaufeli \& Bakker, 2003). Being vigorous entails employees having high levels of energy and mental resilience on the job, willingly investing their effort 
in their work and persisting despite facing difficulties (Schaufeli et al., 2002). As noted by Armstrong and Brown (2009), engaged employees are excited about and interested in their jobs, and put their best efforts into their performance. Schaufeli et al. (2002) go on to explain that dedicated employees feel a sense of inspiration, significance, pride, enthusiasm and challenge in their work. Dedicated employees are highly involved in their work (Bakker \& Demerouti, 2008), and look for opportunities to improve organisational performance and make things better at their organisations (Armstrong \& Brown, 2009). Finally, being absorbed suggests that employees concentrate fully on their work and are deeply engrossed in it, resulting in time passing quickly (Schaufeli et al., 2002). Armstrong and Brown (2009) mention that engaged employees are caught up in their work and, therefore, put in extra discretionary effort when working.

\section{Retention and turnover}

'Retention' is defined by WorldatWork (2007, p. 12) as an organisation's ability 'to keep employees who are valued contributors to organisational success for as long as it is mutually beneficial'. Similarly, Balta (2014) explains the concept of retention as the ability to keep valuable employees by creating and maintaining a working environment that supports staff and encourages them to stay with the organisation for as long as possible, such as by formulating and implementing policies and procedures that address the individual needs of employees. What is common in both these definitions is that organisations typically make efforts to retain staff who are of value to the organisation. Such value typically links to the set of skills possessed by employees, their levels of experience, and/or their high levels of productivity, effectiveness and contributions. It should therefore be an aim of human resource managers not only to recruit and hire employees but also to retain individuals who possess the necessary talents and skills that the organisation requires to achieve its strategic objectives (Scully, Turner \& Gregson, 2014).

However, when employees exit their organisations, turnover as opposed to retention occurs. 'Turnover' can be explained as a permanent form of physical job withdrawal, the cause of which is usually some form of job dissatisfaction. If employees are dissatisfied at work and cannot change their job conditions, then leaving the position may be their only means of solving the problem (Noe, Hollenbeck, Gerhart \& Wright, 2012). An indicator of turnover is whether or not employees intend to leave their organisations in the future. Boshoff, Van Wyk, Hoole and Owen (2002) define intention to quit as the strength of employees' views that they do not wish to stay with their current employers, thus indicating how probable it is that they will leave their organisations in the near future. It is similar to the concept of voluntary turnover, indicating separation because of employees choosing to leave their organisations for professional or personal reasons (Phillips \& Gully, 2012). Intending to quit an organisation is an internal response to numerous factors related to one's personal and organisational life, and can be distinguished from actual turnover because it focusses on the psychological intent to quit, as opposed to the physical act of leaving one's organisation. To ensure that valuable employees are retained within their organisations as opposed to intending to quit, aspects such as remuneration, leadership, challenging job assignments and employee empowerment should be given focus (Bussin, 2011; Milkovich, Newman \& Gerhart, 2011; Preenen, De Pater, Van Vianen \& Keijzer, 2011; Steinman, 2009).

\section{Method}

\section{Research approach}

This study aimed to explore the factors underlying work engagement and retention amongst NPO employees through the use of qualitative, in-depth interviews. The research was phenomenological in nature, aiming to understand as well as interpret how participants give meaning to aspects of their working lives (Fouché, 2002). The function of the research was both descriptive and explanatory by identifying and describing phenomena existing in the NPO work environment as experienced by the sample, as well as exploring the influences surrounding the occurrence of social phenomena, such as what underpins participants' attitudes towards leaving the employment of the NPO sector (Ritchie \& Ormston, 2014).

\section{Research strategy}

From an ethical standpoint, participation in the study was voluntary, with written informed consent being gained and participants being made aware that they could withdraw from the interviews at any stage. Interview data have been kept confidential and made anonymous through no individual names being referred to in this article. Instead, participants are identified by means of their interview slot and country; for example, Participant $D_{(B E)}$ was the fourth participant interviewed in Belgium and Participant $\mathrm{B}_{(\mathrm{SA})}$ was the second participant interviewed in South Africa. The authors adhered to the list of interview ethics laid out by Graham, Grewal and Lewis (2007) before, during and after the interviews took place and obtained ethics clearance permission to conduct the study from Nelson Mandela Metropolitan University (NMMU) in South Africa.

\section{Research design}

The sample consisted of 25 full-time or part-time employees working within NPOs in Belgium and South Africa in a paid capacity. NPOs in Belgium cannot distribute any profits they make to their members, although they are allowed to charge membership fees and organise activities compatible with their purpose in return for payments (Business Belgium, 2010). In a similar manner, NPOs in South Africa are established for public purposes, and none of their income is distributable to their members except as reasonable compensation for services rendered (Department of Social Development, 2011). 
Non-probability purposive and convenience sampling was utilised, with the basis of the purposive sample being selfselection. The authors' personal NPO contacts in South Africa were emailed to invite them to be interviewed, and an invitation to participate was posted on a social media website. This resulted in 15 South African NPO employees being willing to be interviewed. The authors' research assistant in Belgium used similar means to obtain a sample of 10 Belgian employees to be interviewed, resulting in a total sample of 25 participants.

Table 1 provides the demographic distribution of the sample. It is apparent that the majority of the sample was female $(68 \%)$, possessed a postgraduate degree or diploma $(56 \%)$, occupied administrative positions (80\%) and worked within the welfare and humanitarian fields (52\%).

The authors conducted the South African interviews, whereas their research assistant conducted the Belgian interviews. Prior to beginning each interview, information pertaining to the nature of the study was read, including confidentiality of the data collection and participants' rights. Thereafter, an interview consent form was willingly signed by every participant. Once consent had been obtained, a predetermined yet semi-structured list of questions was asked to all participants to ensure standardisation and comparability of answers. Semi-structured interviews provided flexibility to explore interesting aspects that emerged during the interviews (Greeff, 2002). The questions developed were based on theory relating to work engagement and retention. The questions were translated from English into Dutch by a retired Dutch lecturer from NMMU with experience in translation between Dutch and English for the purpose of the Belgian interviews. The interviews were recorded by means of dictaphones so that they could be accurately transcribed and thereafter analysed. The Dutch interviews were

\begin{tabular}{llcc} 
TABLE 1: Demographic distribution of the sample. & & \\
\hline Item & Category & Frequency & Percentage \\
\hline Country & Belgium & 10 & 40.0 \\
& South Africa & 15 & 60.0 \\
Gender & Male & 8 & 32.0 \\
& Female & 17 & 68.0 \\
Education & Matric or grade 12 & 5 & 20.0 \\
& Diploma or higher education & 3 & 12.0 \\
& certificate & & \\
& Bachelor's degree & 3 & 12.0 \\
& Honours or postgraduate & 5 & 20.0 \\
& degree or diploma & & \\
& Master's degree & 7 & 28.0 \\
Type of position in & Doctoral degree & 2 & 8.0 \\
NPO & Administrative & 20 & 80.0 \\
Non-profit category & Strategic or managerial & 5 & 20.0 \\
in which & Animal welfare & 2 & 8.0 \\
respondents work & Conservation and environment & 1 & 4.0 \\
& Cultural activities & 4 & 16.0 \\
& Education and development & 1 & 4.0 \\
& Health care & 3 & 12.0 \\
& Religion, belief and philosophy & 1 & 4.0 \\
& Welfare and humanitarian & 13 & 52.0 \\
\hline
\end{tabular}

$n=25$.

NPO, non-profit organisation. translated into English after transcription by the same Dutch academic for interpretation purposes.

Thematic analysis was utilised to analyse the interviews, which is a method to identify, analyse and report patterns of meaning (known as themes) that occur across a qualitative data set to organise and describe it in 'rich' detail (Braun \& Clarke, 2006). The primary analytical steps that were followed, as discussed in detail by Spencer, Ritchie, $\mathrm{O}^{\prime}$ Connor, Morrell and Ormston (2014), included familiarisation with the data (including transcription of the verbal interview data); constructing an initial thematic framework (which served as a group of headings under which the experiences and views of participants could be organised); indexing and sorting the data (involving providing labels to sections of data that could be grouped together, matching data with themes and summarising data in tabular format); generating initial codes (in order to identify content that was the basis of repeated patterns across the data); reviewing the coherence of data extracts (so that labels could be amended and reapplied to the data); abstracting and interpreting the data (to categorise and classify it according to each theme) and finally, mapping linkages (to conclude how differing aspects of the data might be associated).

\section{Findings}

The two themes that are focussed on in this article are work engagement and retention. The results of the interviews are discussed according to the categories that emerged from each theme, including the various codes comprising each category.

\section{Work engagement}

Questions regarding work engagement were asked in order to shed light on participants' feelings of absorption, dedication and vigour at work, which formed the three categories of the work engagement theme.

\section{Absorption with work}

Three codes emerged with regard to NPO employees being absorbed in their work.

Being engrossed in and involved with one's work: Eight participants from South Africa and seven from Belgium made reference to this point. For example, Participant $A_{(B E)}$ mentioned that the nature of his job in the theatre is such that it swallows him and results in him working when others are relaxing. Along a similar line, Participant $\mathrm{B}_{(\mathrm{BE})}$ thinks of work even when she is exercising, and Participant $\mathrm{J}_{(\mathrm{BE})}$ noted that even when she is not at work, her tasks still occupy her mind. Participant $\mathrm{B}_{(\mathrm{SA})}$ finds herself absorbed when she is learning on the job and conducting research for her work, whilst Participant $M_{(S A)}$ stated that because her NPO does not have sufficient funding to employ more staff, she runs with many projects at one time, which increases her level of excitement and involvement. Participant $\mathrm{G}_{(\mathrm{SA})}$ explained her absorption in her medical work concerning the human immunodeficiency virus (HIV) as follows: 
When I start a task, I focus on it ... when I'm engrossed in something, when I'm enjoying it, then I do get really engaged. In HIV there's so much research that goes on. It's always changing and you have to keep challenging yourself to keep up ... nothing else has managed to keep me engaged for the amount of time that HIV has, so the more I've worked with it, the more passionate I've become about it. (Participant G, Female, Research and Technical Lead)

These responses suggest that employees are personally engaged with their work when they fully employ and express themselves cognitively, physically and emotionally in task behaviours during the performance of their work roles, thus connecting with and harnessing themselves to these roles (Kahn, 1990).

Being focussed on one's work: Eight participants from South Africa and one from Belgium highlighted this point. Participant $\mathrm{F}_{(\mathrm{SA})^{\prime}}$ in his role of residential program manager, works within the lifespace of orphaned or displaced children who live at his NPO. He mentioned that his job is intense and demanding because of being fully committed to the children as they continuously need his support. According to Participant $\mathrm{C}_{(\mathrm{BE})}$, she offers support to children with lifethreatening illnesses when they go abroad on trips that she has organised, which causes her to put in extra work and be highly involved in her tasks to ensure that nothing goes wrong whilst they are away. Participant $\mathrm{M}_{(\mathrm{SA})^{\prime}}$ a trauma counsellor at a psychiatric residency, switches off her mind to everything else when she is working with the residents, and Participant $\mathrm{I}_{(\mathrm{SA})}$ focusses on his tasks because he works towards deadlines and needs to get as much done as possible on a daily basis. Such responses emphasise Bakker's (2015) opinion that the psychological connection that employees have with their work is of critical importance because organisations can only compete effectively when they have inspired and enabled their employees to apply their capabilities fully to their work through being engaged in it.

Working after hours or long hours: Four participants from South Africa and five from Belgium made reference to this code as a means of being absorbed, which is in agreement with the findings of Bakker and Demerouti (2008) who highlight that absorbed employees experience difficulty in detaching themselves from their work. Participant $\mathrm{K}_{(\mathrm{SA})}$ described how she receives phone calls at all hours of the day and initially worked 7 days a week when she established her NPO. Participants $\mathrm{C}_{(\mathrm{SA})^{\prime}} \mathrm{E}_{(\mathrm{SA})}$ and $\mathrm{L}_{(\mathrm{SA})}$ all highlighted that they do not take tea or lunch breaks, with the latter mentioning that she is so focussed on her work that she sometimes forgets when it is time to go home at the end of a day. As noted by Wissing (2014), when individuals are engaged in tasks or situations, they experience a state of flow in which they concentrate intensely and lose their sense of self. Participant $\mathrm{E}_{(\mathrm{BE})}$ noted that she takes her materials home with her after work, and Participant $\mathrm{A}_{(\mathrm{BE})}$ mentioned that he works erratic, irregular hours and cannot leave his job behind when he goes home. According to Participant $\mathrm{D}_{(\mathrm{BE})}$, she is involved in her work during the weekends, and Participant $\mathrm{H}_{(\mathrm{BE})}$ described that he hardly has a work-life balance as a director, because he struggles to switch off from his work and concentrate on his personal life, as work always looms in the background. These anecdotes align with the opinion of Bruce (2011), who states that employees who feel bonded with their organisations will volunteer to stay late at work to finish important tasks, despite this interfering with personal activities. However, such absorption can result in negative effects for NPO employees: as found by Buys and Rothmann (2010), ministers who experience increasing amounts of work are prone to becoming exhausted, a component of burnout.

\section{Dedication to work}

This work engagement category was found to consist of four codes.

Being fully committed and loyal to work: This code was highlighted by seven participants from South Africa and four from Belgium. Participant $\mathrm{C}_{(\mathrm{SA})}$ stated that she is fully committed to her work because she feels valued by her organisation, and Participant $\mathrm{E}_{(\mathrm{BE})}$ highlighted that her commitment arises from her work holding an important place in her life. Participant $\mathrm{F}_{(\mathrm{SA})}$ exhibits loyalty by putting in extra time when needed and going beyond what is required of him because he sees his work as more than just an 8:00 to 17:00 job. Participant $\mathrm{O}_{(\mathrm{SA})}$ demonstrates dedication by continuing to write new proposals for funding even when previous ones are rejected, and Participant $\mathrm{D}_{(\mathrm{SA})}$ is willing to work after hours because she knows that her work is bettering the lives of others. Participant $\mathrm{G}_{(\mathrm{SA})}$ highlighted how work is an important part of her life:

I don't know how not to be dedicated to work ... If I'm not happy at work, I tend to often be unhappy generally. Work is a big component so $\ldots$ being dedicated to my work is often what helps me to engage with it better and to enjoy it better and to do it better. When I start losing dedication to what I'm doing, then it's probably time to be looking for a change. (Participant G, Female, Research and Technical Lead)

Such insights into employee commitment provide evidence for work engagement affecting the mindset of employees to believe in their ability to have a positive impact, as well as promoting greater concerns for quality (Rothmann, 2014).

Go over and above at work: Six South African participants and one Belgian participant made emphasis on this code. For example, Participant $\mathrm{A}_{(\mathrm{SA})}$ stated that she works for the greater good of her NPO by working overtime and not only focussing on core job tasks, and Participant $\mathrm{J}_{(\mathrm{SA})}$ reported going the extra mile by working overtime without extra pay, and helping colleagues when needed. Participant $\mathrm{N}_{(\mathrm{SA})}$ described that she often works 7 days a week or longer without a day off and without receiving extra pay because she is passionate about her work. She noted that:

... I know I put in extra. You know, over and above ... I work consistently. By tomorrow I will have worked nineteen consecutive days without a day off ... I just sort of think, 'well, what's the point because there's stuff to be done. I've got to do this ...' (Participant N, Female, Orchestra Manager) 
Such responses align with the code of working after hours or long hours, indicating both absorption in and dedication to their work. Participant $\mathrm{K}_{(\mathrm{SA})}$ highlighted that she has needed to invest her best efforts as well as time, energy, love and interest into the care centre that she founded for destitute adults and at-risk children to ensure that it grows and becomes a success. Consequently, she has little time for her family and friends. Participant $M_{(S A)}$ noted that she goes over and above at work by organising fun activities for residents, communicating with their families, being on call after hours, and working later than 17:00 when needed. She puts in this extra time because she desires to give her all towards helping psychiatric residents who often come from impoverished backgrounds. As mentioned by Armstrong and Brown (2009), dedicated employees look for, and are given, opportunities to improve organisational performance and actively work to make things better at their work.

Working with intensity: Participant $\mathrm{H}_{(\mathrm{SA})}$ works 11-12 hours per day as well as weekend work, which results in sacrifices to his personal life; yet, he does not receive overtime pay or bonus time. For this reason, he relies on self-motivation as opposed to being dedicated purely to receive a reward. Moreover, Participant $\mathrm{E}_{(\mathrm{SA})}$ works to the best of his ability and will continue to do so until he is asked to retire because he is not working just to have a job or pass time.

Having a sense of pride and respect for work: This final code was mentioned by one participant from South Africa and one from Belgium as a reason for being dedicated to their work. Participant $\mathrm{G}_{(\mathrm{BE})}$ is dedicated to his NPO owing to the sense of pride, responsibility and respect he holds for the organisation, and Participant $\mathrm{K}_{(\mathrm{SA})}$ 's dedication is exhibited in the passion she holds for her work, and the manner in which she upholds standards. This correlates with Schaufeli et al.'s (2002) finding, which highlights pride as an aspect of employee dedication.

\section{Vigour at work}

Twelve South African and all 10 Belgian participants stated that they are energised by their work, which originated from five work-related codes.

Being busy at work: Five South African participants demonstrated their vigour through being busy at work. Participant $\mathrm{M}_{(\mathrm{SA})}$ is energised through constantly having one thing to do after another, and Participant $\mathrm{I}_{(\mathrm{SA})}$ is most energised when having numerous tasks to complete, feeling drained when days are quieter. Participant $\mathrm{D}_{(\mathrm{SA})}$ claimed that she has no time to be idle because she is constantly busy, but despite this is always in high spirits because she is focussed on making a difference in the lives of children. Participant $\mathrm{F}_{(\mathrm{SA})}$ gains energy from developing diverse programmes and having much to do, suggesting that engaged employees experience an energetic connection with their work and perceive that they are able to handle the demands of their jobs (Schaufeli et al., 2002).
Completing tasks, things going right at work and achieving successes at work: Four South African participants reported that they gain energy from this code. According to Participant $\mathrm{H}_{(\mathrm{SA})}$, small successes such as being awarded a tender keep him vigorous in his role of senior conservation officer at an environmental NPO, even though his work is physically exhausting owing to the long hours that he works. Participant $\mathrm{A}_{(\mathrm{SA})}$ works at her optimum energy level when things go well, for example, when her NPO secures large training projects or when corporate social investment initiatives succeed. On the other hand, she experiences work to be emotionally draining when she expends energy yet does not experience positive results. Participant $\mathrm{D}_{(\mathrm{BE})}$ is also stimulated and inspired by work-related achievements, for example, when she hears feedback about her work on the radio. As discussed by Bakker and Demerouti (2008), engaged employees create their own positive feedback through recognition, appreciation and success. In addition, Participant $\mathrm{F}_{(\mathrm{BE})}$ is energised by exerting himself in his role as social worker because he is aware that his work changes the lives of others and holds a great meaning in his life. Participant $\mathrm{L}_{(\mathrm{SA})}$ is always aware that there are far-reaching consequences to her work, which serves to motivate her. She is energised by seeing positive changes in others and being told that she has made an impact. Participant $\mathrm{B}_{(\mathrm{BE})}$ described her source of energy as follows:

When I've done a training session or done a function assessment session and I can see that it has been of value to the people, then I do feel energised. In the same way, when I've done a consultation with someone at a sick-bed and he or she finds it worth their while, well then I derive energy from that as well ... I have the feeling that I can do something, and that that means something to other people. (Participant B, Female, Coordinator of Volunteer Training Centre)

These responses imply that when work is deemed to be meaningful and significant to those performing it, then employees gain energy from their work and as such are engaged in their work. This aligns with findings by Jacobs et al. (2014) and Buys and Rothmann (2010), who discovered that job significance and meaningfulness at work are positively correlated with work engagement.

High levels of excitement at work: One participant from South Africa and two from Belgium mentioned that they enjoy high levels of excitement at work, which aligns with findings by Bakker and Demerouti (2008) who note that engaged employees have positive attitudes and activity levels, and they experience positive emotions such as joy, enthusiasm and happiness. For example, Participant $\mathrm{E}_{(\mathrm{BE})}$ highlighted that every time she begins a new project, she gets new ideas and becomes excited about her work all over again.

Work-related challenges and variety: Four South African participants and one Belgian participant reported that this code is an energy force for them. Participant $\mathrm{B}_{(\mathrm{SA})}$ said that she is energised by setting goals and becoming aware of what has been accomplished versus what still needs to be done. Participant $\mathrm{C}_{(\mathrm{SA})}$ told that she gains energy from the 
challenging nature of her work, such as organising events that are composed of varied tasks. Participant $\mathrm{G}_{(\mathrm{SA})}$ reported that she is re-energised when she takes on new, interesting challenges because these allow her to apply her mind within the scope of what she is allowed to do, thereby overcoming problems and implementing solutions.

Working with a variety of people: One South African participant and two Belgian participants made reference to this code as a source of energy. Participant $\mathrm{F}_{(\mathrm{SA})}$ finds it exciting to work with children and supervise staff, whilst Participant $G_{(\mathrm{BE})}$ described how he is energised by collaborating with others and by being part of a global NPO, which has given him the opportunity to develop international networks. Participant $\mathrm{A}_{(\mathrm{BE})}$ remains alert in mind and spirit by working with individuals of differing ages and backgrounds, and draws energy from the stories and beliefs that they share.

To summarise, this qualitative data relating to work engagement provide support for Rothmann and Rothmann Jr's (2010) proposition that work engagement is consisted of three components, namely, a physical component (being involved in tasks by which both vigour and a positive affective state are demonstrated), a cognitive component (comprising being alert of, absorbed in and involved at work) and an emotional component (in which employees are connected, dedicated and committed to their job and to others whilst working).

\section{Retention}

Interview data related to retention were grouped into two categories by separating responses from participants who desire to leave and those who wish to remain working at their NPOs.

\section{Participants intending to leave their non-profit organisations}

Seven South African participants and five Belgian participants said that they would consider resigning from their NPOs in the future; thus, approximately $50 \%$ of participants may not be successfully retained if these aspects are not given attention by the management. The reasons provided were grouped into 12 codes. (1) Personal growth was mentioned by three South African participants and one Belgian participant, which is to be expected owing to the fact that employees often leave their jobs in order to pursue promotions and better advancement opportunities elsewhere (Aamodt, 2010). Participant $\mathrm{A}_{(\mathrm{SA})}$ feels that her NPO will outgrow her, and that a fresh perspective will be needed within her position. Participant $\mathrm{B}_{(\mathrm{SA})}$ noted that she needs to continue learning and moving forward, whereas Participant $\mathrm{I}_{(\mathrm{SA})}$ feels that his season at his NPO is drawing to an end because he is growing beyond the organisation. Participant $\mathrm{H}_{(\mathrm{BE})}$ specified how he believes that any employee's productivity naturally wanes after 4 years and, thus, a move to another position is necessary to avoid negative productivity.
This is related to another code that arose, namely, participants desiring (2) new experiences, which was discussed by three South African participants and one Belgian participant. Participant $\mathrm{H}_{(\mathrm{BE})}$ explained how employees must add value to their organisations and vice versa in order to retain work pleasure, which occurs when employees move to new positions every 5 years. The benefit for employees is that they embark on new challenges, and organisations gain fresh employees into positions, which stimulates a healthy way of thinking. Participant $A_{(S A)}$ wants to experience working in a corporate organisation because her energy has been drained working within the non-profit sector, and Participant $\mathrm{B}_{(\mathrm{SA})}$ described how she desires to travel and work for a global humanitarian NPO in the future, in the hope that she will experience new challenges and avoid stagnation by staying in one organisation for too long.

(3) Extrinsic rewards or money was mentioned by three South African participants and two Belgian participants as influencing their intentions to quit their NPOs. Participant $\mathrm{B}_{(\mathrm{SA})}$ described how she wants to be independent and move out of the residence that she shares with her parents, but is unable to do so with her current salary. Similarly, pay is the only factor pushing Participant $\mathrm{M}_{(\mathrm{SA})}$ to desire to leave her organisation because she is not earning enough to sustain the lifestyle that she desires. As highlighted by Milkovich, Newman and Gerhart (2011), paying employees too little results in them feeling as if they have been unfairly treated, which further results in their leaving the organisation. This is supported by studies emanating from the NPO sector, such as De Gieter et al. (2008) and Renard and Snelgar (2015), whose findings suggest that being satisfied with one's salary or pay level results in lower turnover intentions amongst NPO employees. Along this line, Participant $\mathrm{J}_{(\mathrm{SA})}$ said that she has gone without a salary for a month, and employees at her NPO have the possibility of not receiving a bonus. Therefore, she desires to move to a sector where pay is more stable, and where annual increases and benefits such as a provident fund, pension fund and medical aid will be provided.

In addition, Participant $B_{(B E)}$ mentioned that she does not currently receive benefits such as a cell phone, laptop and bank card, which might influence her intentions to quit her NPO. This provides support for Perkins and White (2009) who note that employee benefits provided in non-cash form, such as company cars and paid holidays, serve the purpose of retaining employees.

Linked to this is another code, (4) funding, which was highlighted by three South African participants. Participant $\mathrm{J}_{(\mathrm{SA})^{\prime}}$ after mentioning that she has not received a salary for a month, explained how she desires financial stability, but her current job is in jeopardy because of her NPO not receiving their government subsidy. She questions whether this situation will improve, and because her organisation cannot operate without funding, she will only remain working there if the board of directors commits to obtaining donors so that her salary and bonuses would be secured. Along a similar line, 
Participant $\mathrm{N}_{(\mathrm{SA})}$ mentioned that she might have no option but to leave her NPO if they do not obtain funding in the future from the National Lottery in South Africa, and Participant $\mathrm{O}_{(\mathrm{SA})}$ reported that she feels like leaving her job when her funding proposals are rejected, as this is disheartening and demotivating. Such failed fundraising efforts would not be experienced if she worked in a different sector, which leads to the following code, namely (5) the NPO environment, which was highlighted by two participants from South Africa. Participant $\mathrm{I}_{(\mathrm{SA})}$ described his frustrations with his NPO environment, stating that it lacks transparency, is not well regulated, has no culture of control and offers a disconnect between the board and the day-to-day running of the NPO. He desires to work at some other organisation that is more structured.

One South African participant $\left[\mathrm{J}_{(\mathrm{SA})}\right]$ made mention of desiring to leave because she feels (6) under-appreciated owing to the fact that genuinely recognising, valuing and appreciating employees for their contributions is a factor that can lead to turnover if ignored (Steinman, 2009). A Belgian participant $\left[\mathrm{C}_{(\mathrm{BE})}\right]$ noted that she desired to quit her job soon because she was not given any important (7) opportunities at work. Such opportunities might include limited employee empowerment, few opportunities for growth and poor work challenges (Steinman, 2009).

A Belgian Participant $\left[\mathrm{J}_{(\mathrm{BE})}\right]$ highlighted her (8) colleagues as a reason for intending to quit her NPO because she does not have much contact with her coordinator and her colleagues are not easy to work with, which put a dampener on her work atmosphere. Finally, a different Belgian [Participant $\mathrm{F}_{(\mathrm{BE})}$ ] was the only participant to mention the reasons of (9) administration, (10) lack of vision, (11) teamwork and (12) workload or pressure regarding why he desired to leave his NPO as social worker. He noted that for the sake of efficiency and effectiveness, there is often more concern for the completion of forms than for the content of his caregiving and counselling, which can be demotivating. Changes in structures at his NPO have caused problems, and organisational growth placed employees under considerable pressure, with increased workloads for which there was seemingly no solution. The organisation lacked care and a vision, with operations not running smoothly. Internal collaboration between team members was difficult, and changes took place within teams. Aamodt (2010) put forward similar causes of concern when mentioning that employees may quit in order to escape from colleagues, conflict, poor working conditions and/or stress when these become unbearable.

Regarding where participants would choose to work if they left the NPO sector, four South African participants and two Belgian participants specified that they would choose to work in the corporate sector, whilst two South African participants mentioned working for the government. However, three participants from South Africa and four from Belgium would choose to remain working in the non-profit sector. One South African participant and two Belgian participants commented that they would simply desire to work in a position that fulfilled them and which upheld a strong purpose, value and standard, as opposed to a job that focussed solely on making a profit.

\section{Participants desiring to remain working at their non-profit organisations}

Eleven codes emerged with regard to participants being retained within their NPOs, such as (1) being happy, or enjoying or loving one's job or work, which was mentioned by three South African and four Belgian participants. Participant $\mathrm{D}_{(\mathrm{SA})}$ said that she would not leave because she loves her job, and experiences happiness from within as a result of her work. Participant $\mathrm{A}_{(\mathrm{BE})}$ finds energy and beauty within his work daily, whereas Participant $\mathrm{E}_{(\mathrm{BE})}$ derives a great deal of workrelated pleasure.

One South African participant $\left[\mathrm{F}_{(\mathrm{SA})}\right]$ commented that he will not look to move jobs because his current position is (2) where he is meant to be. Along this line, three participants from South Africa discussed that they have been (3) called by God to work in their NPOs and thus would not leave. In particular, Participant $\mathrm{F}_{(\mathrm{SA})}$ described how God had placed him at his NPO for a reason, and he consequently has faith that it is where he should be working. If ever he entertains the idea of leaving, his relationship with God reminds him of why he is there.

Two South African participants highlighted that they are (4) working towards a purpose at their NPOs and thus would not yet consider leaving; for example, Participant $\mathrm{K}_{(\mathrm{SA})}$ discussed how her purpose on earth is to help those in need, and that is why she started her organisation and has a heart for it. This participant was the only one to state that her (5) work at the NPO is not yet finished, and therefore she would never run away from the problems that her NPO faces as this would not solve them. She explained that when she starts something, she must end it and remain motivated throughout, especially because her work directly influences the lives of others.

Furthermore, being given (6) room for growth, or the potential for such growth, encouraged three South African participants to stay at their organisations. For example, Participant $\mathrm{H}_{(\mathrm{SA})}$ sees himself growing in the long term within his NPO, provided that opportunities for development continue to be present. Participant $\mathrm{M}_{(\mathrm{SA})}$ highlighted that she has future opportunities to be promoted into a management position, which makes it worthwhile to stay within the organisation.

Participant $\mathrm{H}_{(\mathrm{SA})}$ does not intend to leave his NPO owing to the (7) autonomy afforded to him in his daily work, as well as because he is (8) fulfilled by the projects he runs, which creates a sense of direction and energy in his life. He was the only participant to mention these reasons. Moreover, only one South African participant $\left[\mathrm{C}_{(\mathrm{SA})}\right]$ noted that (9) a caring environment encourages her to remain working at her NPO. One of the reasons that Participant $\mathrm{E}_{(\mathrm{SA})}$ mentioned for choosing to stay at his organisation is that he (10) does not wish 
to be self-employed, which would be his alternative upon resigning. Participant $\mathrm{G}_{(\mathrm{BE})}$, when asked about what he would do upon resignation, stated that if he were younger he would look for new challenges elsewhere, but because he is (11) close to retiring, he will remain at his current organisation.

Many of these factors align with Steinman's (2009) commentary that employees choose to stay at an organisation because of the fulfilment they gain from their positions, opportunities given to them for personal growth and development, the knowledge that their work makes a difference and that their opinions count, as well as the enjoyment that they gain from their work.

\section{Discussion}

\section{Outline of the findings}

The purpose of this study was to gather in-depth data pertaining to how work engagement and retention can be promoted amongst NPO employees. Table 2 provides a

\begin{tabular}{|c|c|c|}
\hline Theme & Category & Code \\
\hline \multirow[t]{12}{*}{ Work engagement } & \multirow[t]{3}{*}{ Absorption } & $\begin{array}{l}\text { 1. Being engrossed in and involved with } \\
\text { their work }\end{array}$ \\
\hline & & 2. Being focussed on one's work \\
\hline & & 3. Working after hours or long hours \\
\hline & \multirow[t]{4}{*}{ Dedication } & $\begin{array}{l}\text { 1. Being fully committed and loyal to } \\
\text { work }\end{array}$ \\
\hline & & 2. Going over and above at work \\
\hline & & 3. Working with intensity \\
\hline & & $\begin{array}{l}\text { 4. Having a sense of pride and respect } \\
\text { for work }\end{array}$ \\
\hline & \multirow[t]{5}{*}{ Vigour } & 1. Being busy at work \\
\hline & & $\begin{array}{l}\text { 2. Completing tasks or things going right } \\
\text { at work or achieving success at work }\end{array}$ \\
\hline & & 3. High levels of excitement at work \\
\hline & & 4. Work-related challenges and variety \\
\hline & & 5. Working with a variety of people \\
\hline \multirow[t]{23}{*}{ Retention } & \multirow[t]{12}{*}{ Intention to leave } & 1. Personal growth \\
\hline & & 2. New experiences \\
\hline & & 3. Extrinsic rewards or money \\
\hline & & 4. Funding \\
\hline & & 5. The NPO environment \\
\hline & & 6. Feeling under-appreciated \\
\hline & & 7. Lack of opportunities \\
\hline & & 8. Colleagues \\
\hline & & 9. Administration \\
\hline & & 10. Lack of vision \\
\hline & & 11. Teamwork \\
\hline & & 12. Workload or pressure \\
\hline & \multirow[t]{11}{*}{ Intention to stay } & $\begin{array}{l}\text { 1. Being happy or enjoying or loving } \\
\text { one's job or work }\end{array}$ \\
\hline & & 2. Working where one is meant to be \\
\hline & & 3. Called by God \\
\hline & & 4. Working towards a purpose \\
\hline & & 5. Work at the NPO is not yet finished \\
\hline & & 6. Room for growth \\
\hline & & 7. Autonomy \\
\hline & & 8. Fulfilment from projects \\
\hline & & 9. A caring environment \\
\hline & & 10. No desire to be self-employed \\
\hline & & 11. Being close to retirement age \\
\hline
\end{tabular}

NPO, non-profit organisation. summary of the themes, categories and codes found in this regard. It was discovered that the employees under study are indeed absorbed in, dedicated to and energised by their work, which was conceptualised by Schaufeli et al. (2002) as encompassing work engagement. In particular, it is apparent that non-profit employees are willing to invest long hours often to the detriment of their personal lives to ensure that they are meeting the purpose for which their positions and organisations exist. This does not imply that such employees would not feel tired after a day of hard work, but that their tiredness would be experienced as a pleasant state because it is associated with positive accomplishments (Bakker \& Demerouti, 2008). Indeed, the employees under study mentioned that they are energised by work-related successes and accomplishments and possess an exceptional level of commitment to their work. Moreover, participants highlighted that aspects affecting their intentions to stay at their NPOs include working with room for growth, development and autonomy; operating in a caring environment managed by positive, driven leaders whom employees can respect; and enjoying the fact that they gain fulfilment and a sense of purpose from their work tasks.

\section{Practical implications}

The fact that participants were found to be fully committed to their work roles is a positive benefit for the NPOs under study, because work engagement has been found to be positively correlated with improved levels of psychological empowerment, affective organisational commitment, happiness and intrinsic rewards, and negatively correlated with turnover intentions and work alienation (Du Plooy \& Roodt, 2010; Field \& Buitendach, 2011; Jacobs et al., 2014; Stander \& Rothmann, 2010). Rothmann (2014) also highlights positive organisational outcomes that are predicted by work engagement, including improved job satisfaction, motivation, shareholder value and return on assets, and Bakker and Demerouti (2008) note that engaged employees experience better physical health than disengaged employees. Importantly, Bussin (2013) states that no plausible reason exists for why engagement should not impact NPO performance in the same way that it does in for-profit organisations, suggesting that the NPOs under study should maintain the work environments of their employees to sustain their levels of work engagement, thus positively impacting their overall organisational performance.

With regard to retention, this study has revealed important aspects for NPO managers to consider when assessing means to retain valuable staff. Apart from the factors revealed in this study, Steinman (2009) suggests a number of means to reduce voluntary turnover, such as promoting a sense of work-life balance, providing work that is challenging, having one-onone feedback session with employees in which they are encouraged to voice their needs and suggestions, assisting employees in developing the skills necessary to be empowered to fulfil their long-term career aspirations, designing personal career development plans for employees, providing sufficient resources for employees to perform 
their jobs, providing opportunities both for individuals and team work, and building an employment brand that results in employees taking pride in working there. Providing a good work environment and opportunities to advance and grow will also assist in employee retention (Aamodt, 2010).

Aamodt (2010) furthermore notes that attitude surveys and exit interviews can be conducted to determine why employees desire to leave their organisations, as these often discover employee dissatisfaction regarding the content of their work or salary. This was indeed revealed in the present findings. NPOs should therefore be open with their employees regarding how market-related their remuneration is. If salaries are not externally competitive, then adjustments should be made to improve their competitiveness (Steinman, 2009). As noted by Noe et al. (2012), if employees are not paid relatively to the market rate, they will view this as an indication of status and a reflection of their self-worth. Along this line, Peters, Fernandopulle, Masaoka, Chan and Wolfred (2002) recommend that NPO managers should focus on salary competitiveness with other NPOs as well as with similar jobs in for-profit organisations and the government in an effort to improve retention.

That said, it is acknowledged that many NPOs struggle to pay market-related salaries owing to a scarcity of financial resources and funding. In the absence of being able to remunerate their employees according to market rates, Renard and Snelgar's (2015) findings suggest that non-profit employees in South Africa may, to a certain extent, offset their below-market salaries through performing work that is intrinsically rewarding to them, because NPO employees in their sample were more likely to report higher levels of salary satisfaction when they deemed their work to be intrinsically rewarding. Thus, NPOs should place significance on using intrinsic rewards to retain employees. This is because nonprofit employees in this study have indicated that low levels of extrinsic rewards may lead to them experiencing an increased desire to leave their organisations, whereas intrinsic rewards such as growth opportunities, autonomy and purposeful work serve to decrease their turnover intentions. Supporting this, Muteswa and Ortlepp (2011) have shown that a lack of intrinsic rewards, including challenging work and freedom to act on the job, influences managers' intentions to leave their organisations, and Preenen et al. (2011) discovered that the provision of challenging assignments leads to a decrease in turnover intentions. Thus, intrinsic rewards may serve as a means of retaining employees, which indicates an area for future research within the non-profit sector.

It is apparent from the results of this study that participants did not mention that being absorbed in or dedicated to their work would promote their intentions to remain working in their NPOs. Yet, Schaufeli and Bakker (2004), Du Plooy and Roodt (2010), Park and Gursoy (2012), Bothma and Roodt (2013) as well as Robyn and Du Preez (2013) confirm that work engagement is significantly negatively related to employees' intentions to quit their organisations. As mentioned by Bussin (2011), engagement promotes the retention of employees because a critical driver of their intention to quit is their levels of organisational commitment. Engagement should thus be of vital importance for organisations wishing to retain top talent (Bussin, 2011; Nel et al., 2011). Because work engagement entails employees focussing wholeheartedly on their tasks in an intense and concentrated manner, this assumes that they would be enjoying their work and would be psychologically attached to their daily activities, implying that they would not strongly desire to leave their positions. Owing to the fact that work engagement arises from specific job-related resources such as participation in decision-making, task variety, task significance, performance feedback and supervisory support (see Bakker \& Demerouti, 2007; Demerouti, Bakker, Nachreiner \& Schaufeli, 2001), it is likely that engagement in one's work is a direct result of the working environment that one experiences, which should discourage employees from wanting to leave engrossing environments.

\section{Limitations and recommendations}

A limitation of this study was the small sample size through which inferences have been drawn. Coyne (1997) notes that a qualitative sample size is large enough when a theoretical saturation level is reached. Yet, the authors of this study nonetheless acknowledge that a larger sample would have allowed for more meaningful interpretations to take place. It would have been particularly useful for the size of the Belgian sample to have matched that of the South African sample.

It is recommended that future research quantitatively assesses the relationship between rewards (both intrinsic and extrinsic) and the desire of non-profit employees to leave their organisations, because both rewards were found to play a role in the retention of participants. Furthermore, whilst NPO employees in this study are engaged in their work, it has been highlighted that the antithesis of work engagement is burnout, which is linked to compassion fatigue (see Mason et al., 2014). It is possible that NPO employees may experience emotional strain as a result of being too personally vested in their work, particularly if NPO employees are deeply committed to making a difference, thus possibly experiencing emotional exhaustion as a result. It is recommended that future studies investigate whether NPO employees experienced compassion fatigue as a result of their emotional investments at work.

\section{Conclusion}

This study has provided evidence of the means by which NPO employees across two geographically dispersed countries demonstrate their engagement through being enthusiastic, committed and involved in their work. It moreover provided insights into what aspects contribute to these employees desiring either to remain working at or intending to leave the employment of their organisations. This is the first such study to investigate these constructs 
within the non-profit sector in Belgium and South Africa, particularly utilising a qualitative research design which produced in-depth data for analysis. Therefore, it contributes to the knowledge base related to work engagement and retention within both Belgium and South Africa.

\section{Acknowledgements}

The authors wish to thank the South African Reward Association for partly funding this study.

\section{Competing interests}

The data discussed in this article emanate from M.R.'s PhD studies, but have not been published elsewhere or under review in any other publication. The authors declare that they have no financial or personal relationships that may have inappropriately influenced them in conducting the research or writing this article.

\section{Authors' contributions}

M.R. collected this data within the first of three phases of research conducted for her $\mathrm{PhD}$ in Commerce in Industrial Psychology. R.J.S. was her supervisor. M.R. was responsible for authoring this article, with editorial assistance from R.J.S.

\section{References}

Aamodt, M.G. (2010). Industrial/organizational psychology: An applied approach. (6th edn.). Belmont, CA: Wadsworth Cengage Learning.

Armstrong, M., \& Brown, D. (2009). Strategic reward: Implementing more effective reward management. London, UK: Kogan Page.

Bakker, A.B. (2015). Work engagement. Retrieved May 27, 2015, from http://www. arnoldbakker.com/workengagement.php

Bakker, A.B., \& Demerouti, E. (2007). The job demands-resources model: State of the art. Journal of Managerial Psychology, 22(3), 309-328. http://doi.org/10.1108/ 02683940710733115

Bakker, A.B., \& Demerouti, E. (2008). Towards a model of work engagement. Career Development International, 13(3), 209-223. http://doi.org/10.1108/13620 430810870476

Balta, M. (2014). Employee retention. In M.F. Özbilgin, D. Groutsis, \& W.S. Harvey (Eds.), International human resource management (pp. 128-147). Melbourne, Australia: Cambridge University Press.

Boshoff, A.B., Van Wyk, R., Hoole, C., \& Owen, J.H. (2002). The prediction of intention to quit by means of biographic variables, work commitment, role strain and psychological climate. Management Dynamics, 11(4), 14-28.

Bothma, C.F.C., \& Roodt, G. (2013). The validation of the turnover intention scale. SA Journal of Human Resource Management, 11(1), 1-12. http://doi.org/10.4102/ sajhrm.v11i1.507

Braun, V., \& Clarke, V. (2006). Using thematic analysis in psychology. Qualitative ResearchinPsychology,3(2),77-101.http://doi.org/10.1191/1478088706qp063oa

Bruce, A. (2011). Manager's guide to motivating employees. (2nd edn.). Madison, WI: McGraw-Hill.

Business Belgium. (2010). Non-profit organisation (ASBL/VZW). Retrieved June 2, 2015 , from http://business.belgium.be/en/managing_your_business/setting_ up_your_business/company_types/non_profit_organisation/

Bussin, M. (2011). The remuneration handbook for Africa. Randburg, South Africa: Knowres Publishing.

Bussin, M. (2013). Performance management for government, universities, schools and NGOs. Randburg, South Africa: Knowres Publishing.

Buys, C., \& Rothmann, S. (2010). Burnout and engagement of Reformed Church ministers. SA Journal of Industrial Psychology, 36(1), 1-12. http://doi.org/10.4102/ sajip.v36i1.825

Coyne, I.T. (1997). Sampling in qualitative research. Purposeful and theoretical sampling; merging or clear boundaries? Journal of Advanced Nursing, 26(3), 623-630. http://dx.doi.org/10.1046/j.1365-2648.1997.t01-25-00999.x

De Gieter, S., De Cooman, R., Pepermans, R., \& Jegers, M. (2008). Manage through rewards, not only through pay: Establishing the Psychological Reward Satisfaction Scale (PReSS). In M. Vartiainen, C. Antoni, X. Baeten, N. Hakonen, R. Lucas, \& H. Thierry (Eds.), Reward management: Facts and trends in Europe (pp. 97-117) Lengerich: Pabst Science Publishers.
De Gieter, S., Hofmans, J., \& Pepermans, R. (2011). Revisiting the impact of job satisfaction and organizational commitment on nurse turnover intention: An individual differences analysis. International Journal of Nursing Studies, 48(12), 1562-1569. http://doi.org/10.1016/j.ijnurstu.2011.06.007

Demerouti, E., Bakker, A.B., Nachreiner, F., \& Schaufeli, W.B. (2001). The job demandsresources model of burnout. Journal of Applied Psychology, 86(3), 499-512. http://dx.doi.org/10.1037/0021-9010.86.3.499

Department of Social Development. (2011). All about nonprofit organisations. Retrieved June 1, 2015, from http://www.dsd.gov.za/npo/

Derycke, H., Vlerick, P., Burnay, N., Decleire, C., D’Hoore, W., Hasselhorn, H.-M., et al. (2010). Impact of the effort-reward imbalance model on intent to leave among Belgian health care workers: A prospective study. Journal of Occupational and Organizational Psychology, 83(4), 879-893. http://doi.org/10.1348/096317 909X477594

Du Plooy, J., \& Roodt, G. (2010). Work engagement, burnout and related constructs as predictors of turnover intentions. SA Journal of Industrial Psychology, 36(1), 1-13. http://doi.org/10.4102/sajip.v36i1.910

Field, L.K., \& Buitendach, J.H. (2011). Happiness, work engagement and organisational commitment of support staff at a tertiary education institution in South Africa. SA Journal of Industrial Psychology, 37(1), 1-10. http://doi.org/10.4102/sajip. v37i1.946

Fouché, C.B. (2002). Research strategies. In A.S. de Vos (Ed.), Research at grass roots for the social sciences and human service professionals (2nd edn., pp. 270-277). Pretoria, South Africa: Van Schaik.

Glicken, M.D., \& Robinson, B.C. (2013). Treating worker dissatisfaction during economic change. London, UK: Elsevier Inc.

Graham, J., Grewal, I., \& Lewis, J. (2007). Ethics in social research: The views of research participants. Retrieved January 27, 2014, from http://www.civilservice. gov.uk/wp-content/uploads/2011/09/ethics_participants_tcm6-5783.pdf

Greeff, M. (2002). Information collection: Interviewing. In A.S. de Vos (Ed.), Research at grass roots for the social sciences and human service professionals (2nd edn., pp. 291-320). Pretoria, South Africa: Van Schaik.

HayGroup. (n.d.). Employee engagement. Retrieved July 02, 2013, from http://www. haygroup.com/

Jacobs, S., Renard, M., \& Snelgar, R.J. (2014). Intrinsic rewards and work engagement in the South African retail industry. SA Journal of Industrial Psychology, 4O(2) 332-344. http://doi.org/10.4102/sajip.v40i2.1195

Kahn, W.A. (1990). Psychological conditions of personal engagement and disengagement at work. Academy of Management Journal, 33(4), 692-724. http://doi.org/10.2307/256287

Kuttner, R. (2008). Good jobs for Americans who help Americans. Retrieved February 16, 2015, from http://www.prospect.org/article/good-jobs-americans-who-helpamericans

Kyndt, E., Dochy, F., Michielsen, M., \& Moeyaert, B. (2009). Employee retention: Organisational and personal perspectives. Vocations and Learning, 2(3), 195-215. http://doi.org/10.1007/s12186-009-9024-7

Leroy, H., Anseel, F., Dimitrova, N.G., \& Sels, L. (2013). Mindfulness, authentic functioning, and work engagement: A growth modeling approach. Journal of Vocational Behavior, 82(3), 238-247. http://doi.org/10.1016/j.jvb.2013. 01.012

Lewis, J., \& McNaughton Nicholls, C. (2014). Design issues. In J. Ritchie, J. Lewis, C McNaughton Nicholls, \& R. Ormston (Eds.), Qualitative research practice: A guide for social science students and researchers (2nd edn., pp. 47-76). London, UK: Sage.

Lin, C.-P. (2009). Modeling corporate citizenship, organizational trust, and work engagement based on attachment theory. Journal of Business Ethics, 94(4) 517-531. http://doi.org/10.1007/s10551-009-0279-6

Lynn, D.B. (2003). Symposium: Human resource management in nonprofit organizations. Review of Public Personnel Administration, 23(2), 91-96. http:// dx.doi.org/10.1177/0734371X03023002001

Mason, V.M., Leslie, G., Clark, K., Lyons, P., Walke, E., Butler, C., et al. (2014). Compassion fatigue, moral distress, and work engagement in surgical intensive care unit trauma nurses: A pilot study. Dimensions of Critical Care Nursing, 33(4), 215-225. http://doi.org/10.1097/DCC.0000000000000056

Milkovich, G.T., Newman, J.M., \& Gerhart, B. (2011). Compensation. (10th edn.). New York: McGraw-Hill.

Muteswa, R., \& Ortlepp, K. (2011). Contributing factors to potential turnover in a sample of South African management-level employees. Acta Commercii 11, 13-29.

Noe, R.A., Hollenbeck, J.R., Gerhart, B., \& Wright, P.M. (2012). Human resource management: Gaining a competitive advantage (8th edn.). New York: McGrawHill Irwin.

Park, J., \& Gursoy, D. (2012). Generation effects on work engagement among U.S. hotel employees. International Journal of Hospitality Management, 31(4), 1195-1202. http://doi.org/10.1016/j.ijhm.2012.02.007

Perkins, S.J., \& White, G. (2009). Reward management: Alternatives, consequences and contexts (2nd edn.). London, UK: Chartered Institute of Personnel and Development.

Peters, J., Fernandopulle, A., Masaoka, J., Chan, C., \& Wolfred, T. (2002). Help wanted: Turnover and vacancy in nonprofits. Retrieved February 16, 2015, from http://www.compasspoint.org/sites/default/files/docs/research/10_ helpwanted.pdf 
Philanthropy News Digest. (2012). As economy rebounds, nonprofits anticipate more turnover in staff, survey finds. Retrieved February 16, 2015, from http://
philanthropynewsdigest.org/news/as-economy-rebounds-nonprofits-anticipatephilanthropynewsdigest.org/news/
more-turnover-in-staff-survey-finds

Phillips, J.M., \& Gully, S.M. (2012). Strategic staffing. (2nd edn.). Upper Saddle River, $\mathrm{NJ}$ : Pearson Prentice Hall.

Preenen, P.T.Y., De Pater, I.E., Van Vianen, A.E.M., \& Keijzer, L. (2011). Managing voluntary turnover through challenging assignments. Group \& Organization Management, 36(3), 308-344. http://doi.org/10.1177/1059601111402067

Renard, M., \& Snelgar, R.J. (2015). Correlating non-profit employees' levels of salary satisfaction with their intrinsic rewards: A South African study. African Journal of Reward, 1(1), 63-83.

Ritchie, J., \& Ormston, R. (2014). The applications of qualitative methods to social research. In J. Ritchie, J. Lewis, C. McNaughton Nicholls, \& R. Ormston (Eds.) Qualitative research practice: A guide for social science students and researchers (2nd edn.). London, UK: Sage.

Robyn, A., \& du Preez, R. (2013). Intention to quit amongst Generation Y academics in higher education. SA Journal of Industrial Psychology, 39(1), 1-14. http://doi. org/10.4102/sajip.v39i1.1106

Rodríguez-Muñoz, A., Baillien, E., de Witte, H., Moreno-Jiménez, B., \& Pastor, J.C. (2009). Cross-lagged relationships between workplace bullying, job satisfaction
and engagement: Two longitudinal studies. Work \& Stress, 23(3), 225-243. http:// and engagement: Two longitudinal studies
doi.org/10.1080/02678370903227357

Rothmann, S. (2014). Positive institutions. In M. Wissing, J. Potgieter, T. Guse, T. Khumalo, \& L. Nel (Eds.), Towards flourishing: Contexualising positive psychology (pp. 221-261). Pretoria, South Africa: Van Schaik.

Rothmann, S., \& Rothmann S., Jr. (2010). Factors associated with employee engagement in South Africa. SA Journal of Industrial Psychology, 36(2), 1-12. http://doi.org/10.4102/sajip.v36i2.925

Schaufeli, W.B., \& Bakker, A.B. (2003). Utrecht Work Engagement Scale: Preliminary manual (version 1). Retrieved July 17, 2013, from http://www.beanmanaged. com/doc/pdf/arnoldbakker/articles/articles_arnold_bakker_87.pdf

Schaufeli, W.B., \& Bakker, A.B. (2004). Job demands, job resources, and their relationship with burnout and engagement: A multi-sample study. Journal of Organizational Behavior, 25(3), 293-315. http://dx.doi.org/10.1002/job.248

Schaufeli, W.B., Salanova, M., González-Romá, V., \& Bakker, A.B. (2002). The measurement of engagement and burnout: A two-sample confirmatory factor analytic approach. Journal of Happiness Studies, 3(1), 71-92. http://dx.doi org/10.1023/A:1015630930326
Scully, J., Turner, P., \& Gregson, M. (2014). Workforce intelligence planning. In J.R. Crawshaw, P. Budhwar, \& A. Davis (Eds.), Human resource management: Strategic and international perspectives (pp. 118-137). London, United Kingdom: Sage.

Sokkie, P. (2013). The importance of HR management in an NGO environment. Retrieved July 17, 2013, from http://www.bizcommunity.com/Article/196/534/ 91905.html

Spencer, L., Ritchie, J., O'Connor, W., Morrell, G., \& Ormston, R. (2014). Analysis in practice. In J. Ritchie, J. Lewis, C. McNaughton Nicholls, \& R. Ormston (Eds.), Qualitative research practice: A quide for social science students and researchers (2nd edn., pp. 295-345). London, UK: Sage.

Stander, M.W., \& Rothmann, S. (2010). Psychological empowerment, job insecurity and employee engagement. SA Journal of Industrial Psychology, 36(1), 1-8. http://doi.org/10.4102/sajip.v36i1.849

Steinman, S. (2009). Organisational wellness. In Integrated health and wellness: The Employee Wellness Toolkit developed for the Services SETA (2nd edn.). Parktown, South Africa: Services SETA.

Surtees, J., Sanders, K., Shipton, H., \& Knight, L. (2014). HRM in the not-for-profit sectors. In J.R. Crawshaw, P. Budhwar, \& A. Davis (Eds.), Human resource management: Strategic and international perspectives (pp. 296-318). London, UK: Sage.

Tippet, J., \& Kluvers, R. (2009). Employee rewards and motivation in nonprofit organisations: Case study from Australia. International Journal of Business and Management, 4(3), 7-14. http://dx.doi.org/10.5539/ijbm.v4n3p7

Vander Elst, T., Baillien, E., De Cuyper, N., \& De Witte, H. (2010). The role of organizational communication and participation in reducing job insecurity and its negative association with work-related well-being. Economic and Industria Democracy, 31(2), 249-264. http://doi.org/10.1177/0143831X09358372

Van der Vaart, L., Linde, B., De Beer, L., \& Cockeran, M. (2015). Employee well-being, intention to leave and perceived employability: A psychological contract approach South African Journal of Economic and Management Sciences, 18(1), 32-44. http://dx.doi.org/10.17159/2222-3436/2015/v18n1a3

Wissing, M.P. (2014). Selected theories on functioning well and feeling good. In M. Wissing, J. Potgieter, T. Guse, T. Khumalo, \& L. Nel (Eds.), Towards flourishing: Contexualising positive psychology (pp. 141-171). Pretoria, South Africa: Van Schaik.

WorldatWork. (2007). The WorldatWork handbook of compensation, benefits and total rewards. Hoboken, NJ: Wiley.

Yin, R.K. (2011). Qualitative research from start to finish. New York: The Guilford Press. 